\title{
SUPRATROCHLEAR FORAMEN-ANATOMICAL VARIATIONS AND ITS CLINICAL IMPLICATIONS
}

\section{Satish Kumar $S^{1}$, Suresh Kumar $T^{* 2}$.}

${ }^{* 1}$ Associate Professor, Department of Anatomy, Government Dharmapuri Medical College, Dharmapuri, Tamilnadu, India.

${ }^{2}$ Associate Professor, Department of Anatomy, Government Vellore Medical College, Vellore, Tamilnadu, India.

\section{ABSTRACT}

Background: The Supratrochlear foramen (STF) is an important anatomical variation resulting from perforation of olecranon-coronoid septum present between two epicondyles of humerus.

Material and methods: The study was conducted in 78 (41 left side and 37 right side) human dried humeri of unknown sex and age. The topographical anatomy of the STF was studied in detail, morphometric measurements were taken and specimens were photographed. Radiographs of humerus were taken to observe the translucency of septum and the diameter of intramedullary canal was measured at three levels 1 ) below the surgical neck 2) junction between upper $2 / 3^{\text {rd }}$ and lower $1 / 3^{\text {rd }}$ of shaft 3 ) above the olecranon fossa.

Results: Out of 78 bones studied,15 bones showed the presence of STF. The STF was oval, round and triangular in shape in 7, 5 and 3 bones respectively. The mean transverse and vertical diameters of supratrochlear foramen were $5.46 \mathrm{~mm}, 5.82 \mathrm{~mm}$ and $3.94 \mathrm{~mm}, 3.82 \mathrm{~mm}$ on the left and right sides respectively. The mean diameter of the intramedullary canal was $4.51 \mathrm{~mm}$ for the humeri with STF and in the normal humeri it was $5.77 \mathrm{~mm}$.

Conclusion: The knowledge of STF is essential in diagnostic orthopaedics, in intramedullary nailing of humerus in supracondylar fracture. STF is a radiolucent area in radiographs and this may be misinterpreted as osteolytic or cystic lesion.

KEY WORDS: Humerus, supratrochlear foramen, intramedullary canal, translucent septum.

Address for Correspondence: Dr. Suresh Kumar. T, Associate Professor, Department Of Anatomy, Government Vellore Medical college, Vellore, Tamilnadu, India. Mobile:9443746455

E-Mail: rajupr8@yahoo.co.in

Access this Article online

Quick Response code

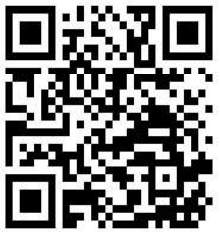

DOI: $10.16965 /$ ijar.2019.230

Journal Information

International Journal of Anatomy and Research

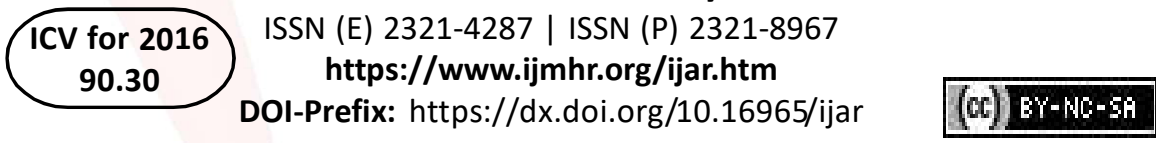

Article Information

Received: 24 May 2019

Peer Review: 24 May 2019

Revised: None
Accepted: 08 Jul 2019

Published (O): 05 Aug 2019

Published (P): 05 Aug 2019

\section{INTRODUCTION}

A thin plate of bone separates the olecranon and the coronoid fossa, which may become perforated in some cases to give rise to a foramen known as "septal aperture" or "supratrochlear foramen"[1]. The STF was first described by Meckel [2]. Since then, it has been described in various animals like dogs, hyenas, cattle and other primates [3,4]. According to Hirsh (1927) the thin plate of bone between the olecranon and coronoid fossa is always present until the age of seven years, after which the bony septum occasionally becomes absorbed to form the STF [5].

Now a days, there has been increased incidence in intramedullary fixation of the humerus following high incidence of traumatic injuries and pathological fractures(6). 
As supracondylar fractures are common in children, it requires proper pinning technique for stable configuration. So the definite structure of humerus and its variations play important role in treatment of supracondylar fractures of humerus to avoid operative errors. Hence present study aims to highlight the incidence, morphological features and clinical importance of STF which might be helpful for Anthropologist, Orthopaedic surgeons and Radiologists.

\section{MATERIALS AND METHODS}

The present study was conducted in 78 dried human humeri of unknown sex from the department of anatomy, Government Dharmapuri Medical college, Dharmapuri. Each humerus was studied for the presence of STF and its shape (oval, round, triangular, sleeve like). The vertical and transverse diameter of the foramen were measured by the digital Vernier caliper.

Radiographs were taken for the humerus with supratrochlear foramen and humerus without the foramen to observe the translucency of septum between coronoid and radial fossa in the lower end of humerus. Measurement of intramedullary canal were taken in radiographs in three levels 1 ) below the surgical neck 2 ) junction between upper $2 / 3^{\text {rd }}$ and lower $1 / \beta^{\text {rd }}$ of shaft 3 ) above the olecranon fossa (fig 3 ).

Fig. 1: Supratrochlear foramen of humerus - A) Oval, B) Circular.

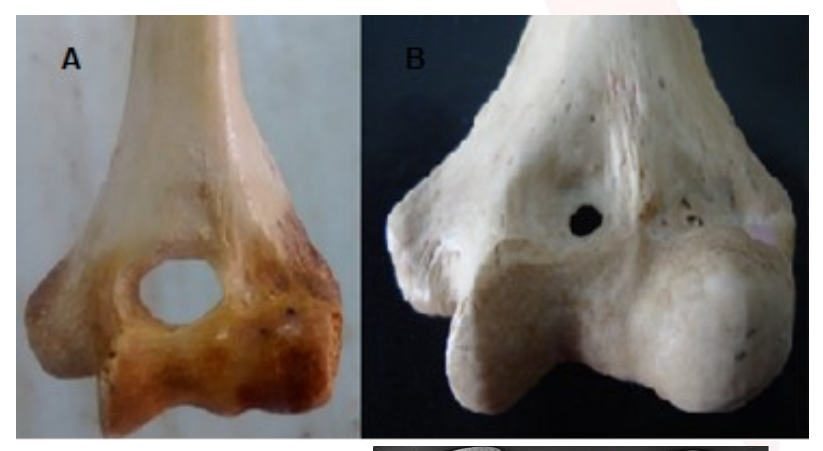

Fig. 2: Radiograph of humerus with $\operatorname{STF}(A)$ \& Translucency of bony septum (B).

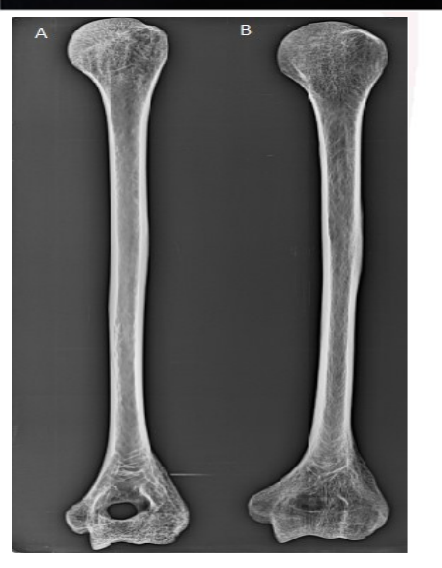

Fig. 3: Measurement of diameter of

Intramedullary canal at 3 levels.

A -Humerus with STF. B- Humerus without STF.

\section{OBSERVATIONS}

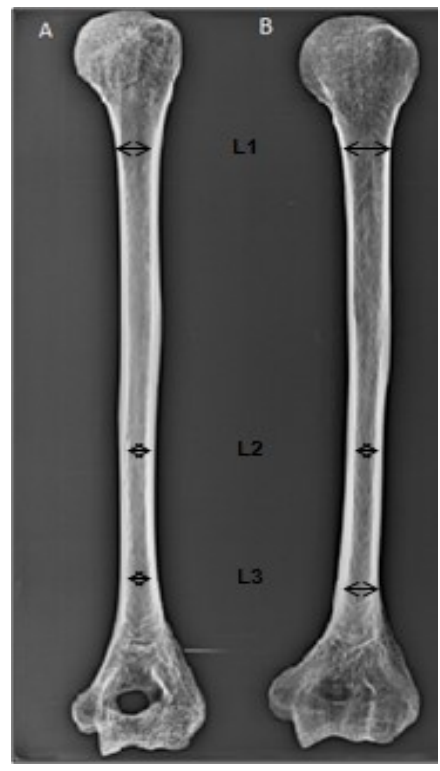

Among 78 specimens of humerus 41 are of left side, 37 are of right side. STF was seen in 15 bones, 9 were left side and 5 were right side. Most common shape of STF was oval $46.6 \%$, followed by round in $33.3 \%$ (Fig 1) and triangular in $20 \%$ (Table 1). The mean transverse, vertical diameter of STF and mean diameter of intramedullary canal at 3 different levels were tabulated in Table 2 and Table 3. The mean diameter of intramedullary canal without STF was $5.77 \mathrm{~mm}$ and with STF was $4.51 \mathrm{~mm}$. Translucency of septum was noticed in 28 specimens (35.8\%) (fig.2).

Table 1: Shape of Supratrochlear Foramen (STF)

\begin{tabular}{|c|c|c|c|}
\hline S. No & Shape of STF & No of Humeri & Percentage \\
\hline 1 & Oval & 7 & $46.70 \%$ \\
\hline 2 & Round & 5 & $33.30 \%$ \\
\hline 3 & Triangular & 3 & $20 \%$ \\
\hline 4 & Sieve & 0 & $0 \%$ \\
\hline
\end{tabular}

Table 2: Different Measurements in Supratrochlear foramen.

\begin{tabular}{|c|c|c|}
\hline Diameter $(\mathrm{mm})$ & Right side & Left side \\
\hline Mean Transverse Diameter & 5.82 & 5.46 \\
\hline Mean Vertical Diameter & 3.94 & 3.82 \\
\hline
\end{tabular}

Table 3: Mean Diameter of Intramedullary Canal of Humerus with and without STF.

\begin{tabular}{|c|c|c|}
\hline Different levels of Humerus & $\begin{array}{c}\text { Mean Diameter of } \\
\text { Intramedullary canal } \\
\text { with STF }\end{array}$ & $\begin{array}{c}\text { Mean Diameter of } \\
\text { Intramedullary canal } \\
\text { without STF }\end{array}$ \\
\hline Below the surgical neck & $4.5 \mathrm{~mm}$ & $5.81 \mathrm{~mm}$ \\
\hline $\begin{array}{c}\text { Junction between upper } 2 / 3 \\
\text { and lower } 1 / 3 \text { of shaft }\end{array}$ & $4.82 \mathrm{~mm}$ & $6.24 \mathrm{~mm}$ \\
\hline Above the coronoid fossa & 4.21 & $5.26 \mathrm{~mm}$ \\
\hline
\end{tabular}


Table 4: Comparative data of incidence of Supratrochlear foramen in human races.

\begin{tabular}{|c|c|}
\hline RACES & INCIDENCE (\%) \\
\hline Americans (Benfer \& Mc kern, 1966) & 6.9 \\
\hline Egyptians (Orztuk et al. 2000) & 7.9 \\
\hline Japanese (Akabori,1934) & 18.1 \\
\hline North Indians (Singh \& singh,1972) & 27.5 \\
\hline South Indians (Singh \& Roa, 2007) & 28 \\
\hline Eastern Indians (Chatterjee,1968) & 27.4 \\
\hline Central Indians (Kate \& Dubey,1970) & 32 \\
\hline South Africans (Nodu et al, 2012) & 32.5 \\
\hline Present study & 19.2 \\
\hline
\end{tabular}

\section{DISCUSSION}

The supratrochlear foramen is a neglected entity in both Anatomy and Orthopaedic text books [7]. Darwin mentioned STF in humans as one of the characteristic that shows man's close relationship to lower forms [10].

The incidence of STF varies in different races (Table 4). In our study the STF was found in $19.2 \%$ bones which coincide with the result of Akabori et al. But Jadhav et al [11] reported a higher incidence of STF $(40.78 \%)$ in their study. STF was more common on left side than right side, which coincides with the findings of Kaur et al [12]. The shape of the STF observed in our study were oval $46.6 \%$, round $33.3 \%$, triangle $20 \%$ which is almost similar to those observed by Diwan et al [13]. Jadhav et al [11] reported a sieve like appearance of STF in $3.22 \%$ of bones in their study but in our study there was no such appearance. Translucent septum was seen on 28 humeri in that $53.5 \%$ of right side humeri and $46.4 \%$ left side humeri in the present study which is almost same as the result of Sunday et al [14].

Number of hypothesis were proposed regarding the cause of supratrochlear foramen. Some opine that it may be a racial anomaly or atavistic [15]. Darwin mentioned STF in humans as one of the characteristics that shows man's close relationship to lower forms [10]. According to Hirsh, the thin plate of bone is always present between olecranon and coronoid fossa up to 7 years after which the bony plate occasionally becomes absorbed to form the STF [16]. Mays suggested that hyperflexion of elbow joint which reabsorbs the humeral septum when the coronoid process of ulna make contact with it [17].

In the present study we observed the mean diameter of the medullary canal was less (4.48 $\mathrm{mm}$ ) in humerus with STF, but in the normal humeri it was $6.36 \mathrm{~mm}$. Akpinar et al [6] studied that the bones with STF have narrow medullary canal (less than $4 \mathrm{~mm}$ ), which makes the retrograde nailing more difficult and increases the chance of secondary fracture of distal end of humerus. Due to the narrowing of distal medullary canal in bones with STF, an ante-grade route has been advocated rather than a retrograde nailing route [18].

Nayak et al [16] observed in plain radiographs that the STF was located closer to medial epicondyle resulting in difficult intramedullary nailing. In our present study the position of STF is located near to the medial epicondyle, it coincides with Nayak et al [16]. The mean distance of the foramen from medial epicondyle is $23.84 \mathrm{~mm}$ and the mean distance from lateral epicondyle is $24.06 \mathrm{~mm}$

De wilde et al [19] mentioned that STF is a relatively radiolucent area, commonly described as "Pseudo lesion" in an $x$ ray of the upper limb and can be mistaken as an osteolytic or cystic lesion. The STF is more common in ancient primitive people than modern man, hence the presence of STF can be a reliable tool for the anthropologists for dating specimen [14].

So the presence of the foramen should be kept in mind during any orthopaedic, surgical and diagnostic procedure on lower end of humerus.

\section{CONCLUSION}

The STF is a neglected but important anatomical variation in the distal end of humerus. Incidence of STF in our present study is $19.2 \%$ with left side prominence. The knowledge of STF is essential for orthopaedic surgeon for preoperative planning in fractures of distal end of humerus and to choose ideal nailing procedure. The radiologist need to be familiar with STF in order to avoid misdiagnosis during interpretation of plain radiographs and CT scans of distal third of the humerus.

\section{ABBREVIATIONS}

STF - Supra-Trochlear Foramen

\section{Conflicts of Interests: None}




\section{REFERENCES}

[1]. Kate B.R and Dubey P.N. A note on the septal apertures in the humerus of Central Indians. E. Anthropol. 1970;33:105-110.

[2]. Mekels JH(1825), cited in Kate BR, Dubey PN. A note on the septal apertures in the humerus of Central Indians. Eastern Anthropologist. 1970;33:270-84.

[3]. Haziroglu RM, Ozer M. A supratrochlear foramen in the humerus of catle. Anat Histol Emryol. 1990;19:106-8.

[4]. Singhal S, Rao V. Supratrochlear foramen of the humerus. Anat Sci Int. 2007;82:105-7.

[5]. Hirsh SI (1927), cited in Morton SH, Crysler WE. Osteo-chondritis dissecans of the supratrochlear septum. J Bone Joint Surg. 1945;27-A:12-24.

[6]. Akpinar F, Aydinlinglu A, Tosun N, Dogan A, Tuncay I, Unal O. A morphometric study on the humerus for intramedullaty fixation. Tohoku J Exp Med. 2003;199:35-42.

[7]. Kumar Ajay, Sharma Anu ,Singh Poonam. A Study of Supratrochlear Foramen of Humerus with its clinical Implication. The Clinical Researcher. 2010;2(2):58-60.

[8]. Sharmila PB, Devi KS. Anatomical note of supratrochlear foramen of humerus in south costal population of Andhra Pradesh. Narayana Medical Journal. 2012.1(2).

[9]. Benfer, McKernT .The correlation of bone robusticity with the perforation of the coronoid-olecranon septum of humerus of man. Am J PhysAnthropol 1966;24:247-252.

[10]. Krishnamurthy A, Yelicharla AR, Takkalapalli A, Munishamappa V, Bovindala EB, Chandramohan M. Supratrochlear foramen of humerus-a morphometric study.Int J Biol Med Res.2011;2(3):829-31.

[11]. Jadhav M, Tawte A, Pawar P, Mane S. Anatomical study of supratrochlear foramen of Humerus. J Res Med Den Sci 2013;1(2):33-35.

[12]. Jaswider Kaur , Zora Sing. Supratrochlear Foramen of Humerus - A Morphometric Study. Indian Journal of Basic and Applied Medical Research; June 2013: Issue-7,Vol-2 P. 651-654
[13]. Diwan RK, Rani A, Anita R, Chopra J, Srivastava AK, Sharma PK, Verma RK, Pankaj AK. Incidence of Suprtrochlear foramen of Humerus in North Indian Population. Biomedical Research 2013;24(1):142145.

[14]. Sunday OO, Olusegun OS, Oluwabunmi BM. The Supratrochlear Foramen of the Humerus: Implications for intramedullary nailig in distal Humerus. Journal of Biology, Agriculture and Healthcare. 2014;4(7): 136-139.

[15]. Bindhu HA, Rao NB. Supratrochlear foramen - A Phylogenetic remnant. International Journal of Basic and Applied Medical Sciences 2013;3(2):130-132.

[16]. Nayak SR, Das S, Krishnamurthy A, Prabhu L V, Potu BK. Supratrochlear foramen of the humerus: an anatomico-radiological study with clinical implications. Ups J Med Sci. 2009;114:90-4.

[17]. Mays S. Septal aperture of the humerus in a mediaeval human skeletal population. American Journal Physical Anthropology.2008;136:432-440.

[18]. Paraskevas GK, Papaziogas B, Tzaveas A Giaglis G, Kitsoulis $P$, Natsis k. The Supratrochlear foramen of the humerus and its relations to the medullary canal: a potential surgical application . Med Sci Monit. 2010 April;16(4):119-123.

[19]. De Wilde V, De Maeseneer M, Lenchik L, Van Roy P, Beeckman P, Osteaux M. Normal Osseous variants presenting as cystic or lucent areas on radiography and CT imaging : A pictorial overview. Eur j. Radiol.2004;51:77-84.

[20]. Ozturk A,Kutlu C, Bayraktar B,Zafer ARI, Sahinoglu $K$. The supratrochlear foramen septum in the humerus (Anatomical study). St.Tp Fak. Mecmuas.2000;63:72-76.

[21]. Akabori.E. Septal apertures in the humerus in Japanese, Ainu and Koreans. Am J Phys Anthropol.1934;18:395-400.

[22]. Chatterjee KP. The incidence of perforation of olecranon fossa in the humerus among Indians. Eastern Anthropologist. 1968;21:270-284.

How to cite this article:

Satish Kumar S, Suresh Kumar T. SUPRATROCHLEAR FORAMENANATOMICAL VARIATIONS AND ITS CLINICAL IMPLICATIONS. Int J Anat Res 2019;7(3.2):6807-6810. DOI: 10.16965/ijar.2019.230 